\title{
Critical role of natural organic matter in photodegradation of methylmercury in water: Molecular weight and interactive effects with other environmental factors
}

\author{
Dan Zhang ${ }^{\mathrm{a}, \mathrm{b}}$, Yongguang Yin ${ }^{\mathrm{a}}$, Yanbin $\mathrm{Li}^{\mathrm{c}}$, Yong Cai ${ }^{\mathrm{d}}$, Jingfu Liu ${ }^{\mathrm{a}, *}$ \\ a State Key Laboratory of Environmental Chemistry and Ecotoxicology, Research Center for Eco-Environmental Sciences, Chinese Academy of Sciences, Beijing 100085, China \\ b University of Chinese Academy of Sciences, Beijing 100049, China \\ c Key Laboratory of Marine Chemistry Theory and Technology, Ministry of Education, Ocean University of China, Qingdao 266100, China \\ ${ }^{\mathrm{d}}$ Institute of Environment and Health, Jianghan University, Wuhan 430056, China
}

\section{H I G H L I G H T S}

- NOM can significantly inhibit the $\mathrm{Fe}^{3+}$ induced degradation of $\mathrm{MeHg}$.

- High molecular weight NOM shows higher light attenuation-induced degradation inhibition.

- Photodegradation-mediated by NOM is also affected by $\mathrm{pH}$ and co-existing $\mathrm{Cl}^{-}$ and $\mathrm{NO}_{3}^{-}$.

\section{G R A P H I C A L A B S T R A C T}

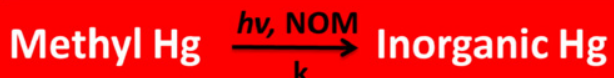
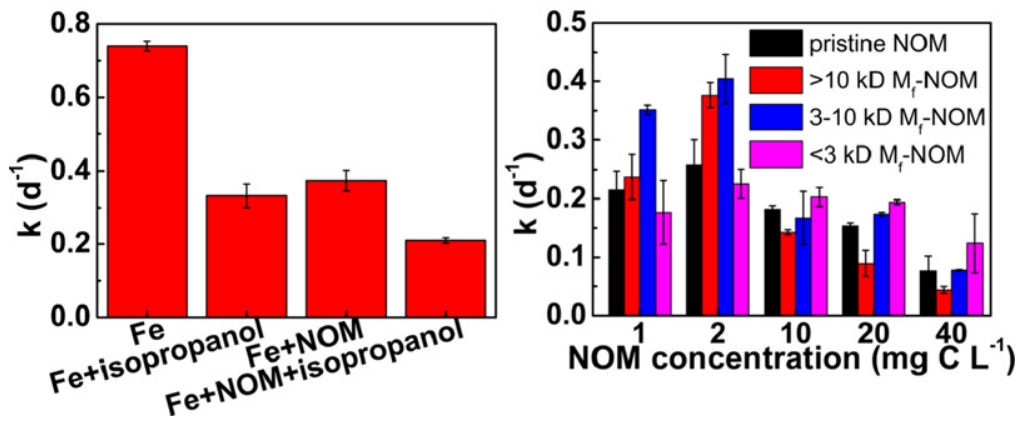

\begin{abstract}
A B S T R A C T
Photodegradation is the main depletion pathway of methylmercury (MeHg) in surface water. However, the underlying mechanism of MeHg photodegradation is still not well understood. In this study, the critical role of natural organic matter (NOM) from Suwannee River natural organic matter of the International Humic Substance Society, especially its molecular weight, and the impacts of other related environmental factors in $\mathrm{MeHg}$ photodegradation were investigated. We observed that $\mathrm{MeHg}$ cannot photo-degrade in de-ionized water, excluding the direct photodegradation of MeHg. While either $\mathrm{NOM}$ or $\mathrm{Fe}^{3+}$ alone induced MeHg photodegradation, co-existing NOM significantly inhibited the $\mathrm{Fe}^{3+}$-induced degradation, highlighting the critical and complex role of NOM in MeHg photodegradation. Additionally, MeHg exhibited different photodegradation rates in the presence of molecular weight fractionated natural organic matter $\left(\mathrm{M}_{\mathrm{f}}-\mathrm{NOM}\right)$. More importantly, high concentration of NOM caused light attenuation significantly inhibited the photodegradation of MeHg, which was more significant for high molecular weight $\mathrm{M}_{\mathrm{f}}-\mathrm{NOM}$. In the presence of $\mathrm{M}_{\mathrm{f}}-\mathrm{NOM}$, MeHg photodegradation was also affected by light quality, $\mathrm{pH}$ and co-existing $\mathrm{Cl}^{-}$and $\mathrm{NO}_{3}^{-}$. The study is helpful for a better understanding of the critical role of NOM and other environmental factors on $\mathrm{MeHg}$ photodegradation in surface water.
\end{abstract}

(c) 2016 Elsevier B.V. All rights reserved.

\footnotetext{
* Corresponding author at: 18 Shuangqing Road, Haidian District, Beijing 100085, China.

E-mail address: jfliu@rcees.ac.cn (J. Liu).
} 


\section{Introduction}

Methylmercury (MeHg), the most toxic mercury species, is ubiquitous in the aquatic environment (Mergler et al., 2007). It is a potent neurotoxin and easy to be accumulated and magnified in the food chains, posing a potential threat to wildlife as well as humans (Julvez et al., 2010; Morel et al., 1998). MeHg can be produced in sediment from inorganic mercury by a variety of anaerobic bacteria, especially sulfate-reducing bacteria and iron reducing bacteria (Fleming et al., 2006; Gilmour et al., 1992; Parks et al., 2013), and then released into the surface water. Toxic MeHg in the water can be degraded into less toxic inorganic mercury through biological and non-biological pathways (Whalin et al., 2007). Although the microbial degradation of MeHg occurs in sediment (Oremland et al., 1991) and water (Marvin-Dipasquale and Oremland, 1998; Schaefer et al., 2004), photodegradation is the main depletion way of $\mathrm{MeHg}$ from surface water (Hammerschmidt and Fitzgerald, 2006; Li et al., 2010; Sellers et al., 1996). It has been demonstrated that photodegradation can remove a large portion of $\mathrm{MeHg}$ in surface water (Hammerschmidt and Fitzgerald, 2006; Hines and Brezonik, 2007; Lehnherr and St. Louis, 2009), resulting in the decrease in the concentration of $\mathrm{MeHg}$ in water. This photochemical process plays a critical role in the biogeochemical cycling of mercury in aquatic environments (Hammerschmidt and Fitzgerald, 2006; Sellers et al., 1996).

Revealing the underlying mechanism and controlling factors of $\mathrm{MeHg}$ photodegradation is of great importance to understand MeHg cycling and develop techniques to reduce the concentration of $\mathrm{MeHg}$ in aquatic environments. Although great efforts have been made in investigating $\mathrm{MeHg}$ photodegradation, there are still several open questions regarding this MeHg photodegradation. While some studies put forward that MeHg could be degraded in de-ionized water under sunlight (Black et al., 2012), other studies suggested MeHg cannot be photodegraded in deionized water (Hammerschmidt and Fitzgerald, 2010; Tai et al., 2014; Zhang and Hsu-Kim, 2010). An iron-mediated pathway of MeHg photochemical decomposition, involving the hydroxyl radical produced by photo-Fenton reaction, was also proposed (Hammerschmidt and Fitzgerald, 2010). However, although this ironinduced $\mathrm{MeHg}$ photodegradation was further demonstrated in de-ionized water (Kim and Zoh, 2013), it was observed that the addition of iron (at $10 \mu \mathrm{mol} \mathrm{L}{ }^{-1}$ ) into natural surface waters showed negligible effect on MeHg photodegradation (Black et al., 2012). In contrast, recent studies suggested that the formation of $\mathrm{MeHg}$-natural organic matter (NOM) complex may be a key step in MeHg photodegradation (Qian et al., 2014; Tai et al., 2014; Zhang and Hsu-Kim, 2010). It should be noted that although the impact of inorganic ions (e.g. $\mathrm{Cl}^{-}, \mathrm{NO}_{3}^{-}$, and $\mathrm{Fe}^{3+}$ ) (Kim and Zoh, 2013; Sun et al., 2013) on MeHg photodegradation has been investigated, most of these studies were performed in the absence of NOM. Since MeHg in surface water generally binds with NOM (Khwaja et al., 2010), the effect of co-existing ions on $\mathrm{MeHg}$ photodegradation should be studied in the presence of NOM. Moreover, as NOM is a polydispersed mixture with molecular weight from $<100$ Da to over $300 \mathrm{kDa}$ (Mostofa et al., 2013), understanding the differential roles of different molecular fractions of $\mathrm{NOM}$ on $\mathrm{MeHg}$ photodegradation is also of great interesting, which unfortunately is still not well known. Our previous study showed that molecular weight fractionated natural organic matters $\left(\mathrm{M}_{\mathrm{f}}-\mathrm{NOM}\right)$ have differential structural and light attenuation characteristics (Yin et al., 2014). Thus, we proposed that these differences could also result in the different effects of various fractionated $\mathrm{M}_{\mathrm{f}}-\mathrm{NOM}$ in $\mathrm{MeHg}$ photodegradation.

The primary objective of this study was to assess the role of NOM and co-existing ions on $\mathrm{MeHg}$ photodegradation. To fulfill this aim, we investigated (i) the critical role of NOM and its effect on $\mathrm{Fe}^{3+}$-induced $\mathrm{MeHg}$ photodegradation; (ii) the differential photodegradation of $\mathrm{MeHg}$ in $\mathrm{M}_{\mathrm{f}}-\mathrm{NOM}$ solution; and (iii) the effect of environmental factors and water constituents (i.e. light quality, $\mathrm{pH}$, co-existing $\mathrm{Cl}^{-}$and $\mathrm{NO}_{3}^{-}$) on $\mathrm{MeHg}$ photodegradation in the presence of NOM.

\section{Materials and methods}

\subsection{Materials}

Suwannee River natural organic matter (SRNOM) obtained from the International Humic Substance Society (St. Paul, MN, USA) was used as a NOM model. Enriched ${ }^{198} \mathrm{HgCl}_{2}$ and ${ }^{201} \mathrm{HgCl}_{2}$ were purchased from Trace Sciences International (Ontario, Canada). $\mathrm{Me}^{198} \mathrm{Hg}$ and $\mathrm{Me}^{201} \mathrm{Hg}$ were synthesized by methylcobalamin according to our previous study (Ma et al., 2014). Amicon Ultra-15 centrifugal devices with molecular cut off $3 \mathrm{kDa}$ and $10 \mathrm{kDa}$, respectively, were obtained from Millipore (Darmstadt, Germany).

Two types of films were used to evaluate the effects of light quality on the MeHg degradation. UV films from Energy-Film (Portland, OR), which can absorb UV-A and UV-B, were defined as UV-block film. Mylar films from United States Plastic Corp. (Lima, OH, USA), which can absorb UV-B, were used as UV-B-block film. The light transmissions of the films have been characterized in our previous study (Yin et al., 2014).

\subsection{Preparation of SRNOM stock solution and $M_{f}-N O M$ fractions}

$1 \mathrm{~g} \mathrm{~L}^{-1}$ stock solution of SRNOM was prepared in de-ionized water and shaken for $12 \mathrm{~h}$ at room temperature in the dark. Then the solution was filtered through $0.22 \mu \mathrm{m}$ cellulose nitrate membrane. This filtered solution was defined as pristine SRNOM.

Ultrafiltration was used to prepare $\mathrm{M}_{\mathrm{f}}-\mathrm{NOM}$ with different molecular weights. The Amicon Ultra-15 centrifugal devices were initially rinsed with de-ionized water to remove glycerol. Then, add up to $15 \mathrm{~mL}$ of the pristine SRNOM into the $10 \mathrm{kDa}$ Amicon Ultra- 15 centrifugal device and centrifuged for $30 \mathrm{~min}$ at $6654 \mathrm{~g}$ by a Sigma 3-18 K centrifuge (St. Louis, MO). The retentate was rinsed with de-ionized water and collected as $>10 \mathrm{kDa} \mathrm{M} \mathrm{M}_{\mathrm{f}}-\mathrm{NOM}$. Then the filtrate was transferred into $3 \mathrm{kDa}$ Amicon Ultra-15 centrifugal device and centrifuged for $30 \mathrm{~min}$ at $8422 \mathrm{~g}$. The retentate was collected as 3-10 $\mathrm{kDa} \mathrm{M}_{\mathrm{f}}-\mathrm{NOM}$ and the filtrate as $<3 \mathrm{kDa} \mathrm{M}_{\mathrm{f}}-\mathrm{NOM}$. All solutions were stored in the dark at $4{ }^{\circ} \mathrm{C}$ in the refrigerator ahead of use.

\subsection{Characterization of pristine and $M_{f}-N O M$}

The concentrations of pristine and $\mathrm{M}_{\mathrm{f}}-\mathrm{NOMs}$ were analyzed by a Teledyne Tekmar total organic carbon (TOC) fusion analyzer (Mason, Ohio, USA). The molecular weight distribution of $\mathrm{M}_{\mathrm{f}}-\mathrm{NOM}$ fractions is shown in Fig. S1. The recovery of TOC was $88.7 \%$. NOM loss during the fractionation was mainly ascribed to the membrane adsorption and the washing process.

The details regarding the UV-vis and fluorescence excitation-emission characterization of the pristine and $\mathrm{M}_{\mathrm{f}}-\mathrm{NOM}$ used in the experiment were available in the SI (Peuravuori and Pihlaja, 1997; Richard et al., 2004; Shen et al., 2015; Yin et al., 2014). These results (Fig. S2 and S3) suggested high molecular weight $\mathrm{M}_{\mathrm{f}}$-NOM contained more aromatic moieties, while low molecular weight $\mathrm{M}_{\mathrm{f}}-\mathrm{NOM}$ contained abundant carboxyl groups.

\subsection{Measurement of $\mathrm{MeHg}$ photodegradation rate constants}

The simulated sunlight was provided by a sunlight-simulator (TEMI880, Beifang Lihui, Beijing, China) equipped with three air-cooled Xe lamp (2500 W). The light intensity was set to $550 \mathrm{~W} \mathrm{~m}^{-2}$ and the temperature was controlled at $\sim 35{ }^{\circ} \mathrm{C}$. The experiments were performed in quartz bottles ( $100 \mathrm{~mL}$ ) with quartz caps to avoid the adsorption of MeHg on the bottle surface. The total volume of the solution was $100 \mathrm{~mL}$. Me ${ }^{198} \mathrm{Hg}$ was spiked into quartz bottles to a final concentration of $15.0 \mathrm{ng} \mathrm{L}^{-1}$. In previous study, it has been demonstrated that the pathway of MeHg photodegradation is controlled by $\mathrm{MeHg} / \mathrm{NOM}$ ratio, but not the concentration of MeHg or NOM (Zhang and Hsu-Kim, 
2010). Therefore, MeHg concentration at $15.0 \mathrm{ng} \mathrm{L}^{-1}$ was used in our study to facilitate the sampling and analysis. $10 \mathrm{mmol} \mathrm{L}^{-1}$ phosphate was used to buffer the solution. Pristine- or $\mathrm{M}_{\mathrm{f}}-\mathrm{NOM}$ at different concentration was added to evaluate the role of NOM in the photodegradation of MeHg. Duplicate samples were prepared for each experiment. $5 \mathrm{~mL}$ solution was taken from each bottle after $0,1,2,3$, 4, 5 days of incubation. Isotope dilution technique based on aqueous ethylation and purge-and-trap pre-concentration followed by gas chromatography-inductively coupled plasma mass spectroscopy was applied in analysis of $\mathrm{MeHg}$, and detailed instrumentation and procedure could be referred to our previous study (Ma et al., 2014). A model based on first-order chemical kinetics was used to describe the photodegradation of MeHg in the water (Eq. (1)) (Li et al., 2010; Tai et al., 2014). After integration of Eq. (1), $\ln \left(C_{\mathrm{MeHg}}\right)_{\mathrm{t}}$ was simulated by $\ln \left(C_{\mathrm{MeHg}}\right)_{0}$, as described in Eq. (2). The rate constant of MeHg degradation, $k$, was then obtained by linear regression of $\ln \left(C_{\mathrm{MeHg}}\right)_{\mathrm{t}}$ on $t$.

$\frac{\mathrm{d} C_{\mathrm{MeHg}}}{\mathrm{d} t}=-k \times C_{\mathrm{MeHg}}$

$\ln \left(C_{\mathrm{MeHg}}\right)_{\mathrm{t}}=\ln \left(C_{\mathrm{MeHg}}\right)_{0}-k \times t$

where $C_{\mathrm{MeHg}}$ is the concentration of $\mathrm{MeHg}\left(\mathrm{ng} \mathrm{L}^{-1}\right) ; k$ is the rate constant of MeHg photodegradation $\left(\mathrm{d}^{-1}\right), t$ is the incubation time (d).

\subsection{Evaluation of light attenuation effect}

The light attenuation effect from NOM was evaluated by using monochromatic irradiation (366 nm) provided with a mercury lamp $(100 \mathrm{~W})$ on the rotation reactor (XPA, Xujiang Electromechanics, Nanjing, China). The experiments were performed in $50 \mathrm{~mL}$ quartz glass tubes with quartz caps ( $50 \mathrm{~mL}, 2.2 \mathrm{~cm}$ diameter). The corrected $\mathrm{MeHg}$ photodegradation rate constant, $k_{\lambda \text {, corrected }}$ in the presence of pristine and $\mathrm{M}_{\mathrm{f}}-\mathrm{NOM}$, was calculated following Eq. (3) (Yin et al., 2014),

$k_{\lambda, \text { corrected }}=\frac{k_{\lambda}}{S_{\lambda}}=\left(2.303 k_{\lambda} \alpha_{\lambda} l\right) /\left(1-10^{-\alpha_{\lambda} \lambda}\right)$

where $k_{\lambda}$ is the degradation rate constant calculated from Eq. (2), $S_{\lambda}$ is the light attenuation factor, $\alpha_{\lambda}$ is the decadic absorption coefficient of the solution at $366 \mathrm{~nm}$, and $l$ is the light path length of the reaction cell $(2.2 \mathrm{~cm})$. Detailed calculation of these parameters was given in our previous study (Yin et al., 2014).

\subsection{Effects of light quality, $\mathrm{pH}$, and other co-existing ions on $\mathrm{MeHg}$ degradation}

Previous studies have demonstrated light quality has great impacts on $\mathrm{MeHg}$ photodegradation (Fernandez-Gomez et al., 2013; Lehnherr and St. Louis, 2009; Li et al., 2010). To evaluate the effect of light quality in simulated sunlight on MeHg degradation, the quartz bottles were wrapped with UV-B-block film (UV-A + Vis), UV-block film (Vis) and without film (full radiation), respectively. Natural environment waters have different water chemistry such as different $\mathrm{pH}$ ranges (5 to 9; Zepp et al., 1992) and different concentration of $\mathrm{Fe}^{3+}$ (1.2 to $16.8 \mathrm{~mol} \mathrm{~L}^{-1}$; Lofts et al., 2008), $\mathrm{Cl}^{-}$(up to $0.5 \mathrm{~mol} \mathrm{~L}^{-1}$; Chen et al., 2003), $\mathrm{NO}_{3}^{-}\left(10^{-5}\right.$ to $10^{-3} \mathrm{~mol} \mathrm{~L}^{-1}$; Shankar et al., 2007), which could directly or indirectly influence $\mathrm{MeHg}$ photodegradation. To evaluate the influence of $\mathrm{pH}$ on $\mathrm{MeHg}$ photodegradation, the $\mathrm{pH}$ of the solution was adjusted to 5.0,6.0, 7.0, 8.0, and 9.0, respectively, by using $10 \mathrm{mmol} \mathrm{L}^{-1}$ phosphate buffer. The effect of co-existing ions on $\mathrm{MeHg}$ photodegradation, including $\mathrm{Cl}^{-}\left(0-800 \mathrm{mmol} \mathrm{L}^{-1}\right), \mathrm{NO}_{3}^{-}\left(0_{-}\right.$ $\left.2 \mathrm{mmol} \mathrm{L}^{-1}\right)$, and $\mathrm{Fe}^{3+}\left(2 \mu \mathrm{mol} \mathrm{L}^{-1}\right)$, was also investigated at $\mathrm{pH} 6.0$ in the presence of $2.0 \mathrm{mg} \mathrm{C} \mathrm{L}^{-1}$ pristine or $\mathrm{M}_{\mathrm{f}}-\mathrm{NOM}$.

\section{Results and discussion}

\subsection{Critical and complex role of NOM in MeHg photodegradation}

Firstly, the possible direct photodegradation of MeHg in de-ionized water was investigated under simulated sunlight. Results (Fig. S4) showed that, under light radiation, the degradation of MeHg in de-ionized water was negligible, excluding the direct photodegradation pathway of MeHg. Most previous studies also proposed MeHg cannot be degraded in de-ionized water under the wavelength of the solar spectrum (Qian et al., 2014; Zhang and Hsu-Kim, 2010). However, a study suggested the photo-degradation of $\mathrm{MeHg}$ at relatively high rates in high purity water with no trace metals or NOM (Black et al., 2012). These different results could possibly be derived from the different adsorption of MeHg on the vessel materials (borosilicate/quartz vs. Teflon). The observed high "photodegradation" of MeHg in de-ionized water could possibly be ascribed to the adsorption of mercury on the coarse Teflon surface (Rong et al., 2001) in the absence of ligands (e.g. $\mathrm{NOM}, \mathrm{Cl}^{-}$), but not to real photodegradation.

Considering the "controversial" observation of $\mathrm{Fe}^{3+}$ and NOM on $\mathrm{MeHg}$ photodegradation, their effects on indirect photodegradation of $\mathrm{MeHg}$ were then investigated respectively. $\mathrm{Fe}^{3+}$ widely exists in the surface water, with a concentration ranging from 1.2 to $16.8 \mu \mathrm{mol} \mathrm{L} \mathrm{L}^{-1}$ (Lofts et al., 2008). In previous study, Hammerschmidt and Fitzgerald (2010) revealed that hydroxyl radical produced by $\mathrm{Fe}^{3+}$-mediated photo-Fenton reaction was the main pathway of $\mathrm{MeHg}$ decomposition in an arctic Alaskan lake. This $\mathrm{Fe}^{3+}$-accelerated $\mathrm{MeHg}$ decomposition (up to 7.5 times) was further demonstrated under UVA light ( $365 \mathrm{~nm}$ ) by Kim and Zoh (2013). However, in another study, Black et al. observed that the addition of $10 \mu \mathrm{mol} \mathrm{L}{ }^{-1} \mathrm{Fe}^{3+}$ into surface waters from wetland field resulted in an $11 \%$ decrease of $\mathrm{MeHg}$ decomposition (Black et al., 2012). Therefore, the role of $\mathrm{Fe}^{3+}$ in $\mathrm{MeHg}$ photodegradation, especially in the presence of NOM, needs to be clarified further. As shown in Fig. 1, the addition of $2 \mu \mathrm{mol} \mathrm{L} \mathrm{L}^{-1} \mathrm{Fe}^{3+}$ in the absence of NOM significantly induced $\mathrm{MeHg}$ photodegradation. The $\mathrm{MeHg}$ degradation was not observed in the presence of $\mathrm{Fe}^{3+}$ under dark conditions, suggesting a synergistic effect of $\mathrm{Fe}^{3+}$ and light. The fact of non-degradation of $\mathrm{MeHg}$ under dark conditions also indicated that the photodegradation in the presence of $\mathrm{Fe}^{3+}$ was not from an artifact of adsorption of $\mathrm{MeHg}$ on the iron colloids. Similarly, under dark conditions, degradation of MeHg was not evident in the presence of NOM (Fig. S4). However, in the presence of both NOM and simulated light, significant degradation of MeHg was observed. This was consistent with previous studies, which demonstrated that the formation of MeHg-NOM complex was a key step in the MeHg photodegradation (Qian et al., 2014; Tai et al., 2014; Zhang and Hsu-Kim, 2010). Theoretically, the singlet-triplet excitation energies of $\mathrm{MeHg}-\mathrm{OH}$ and $\mathrm{MeHg}-\mathrm{Cl}$ are too high to undergo

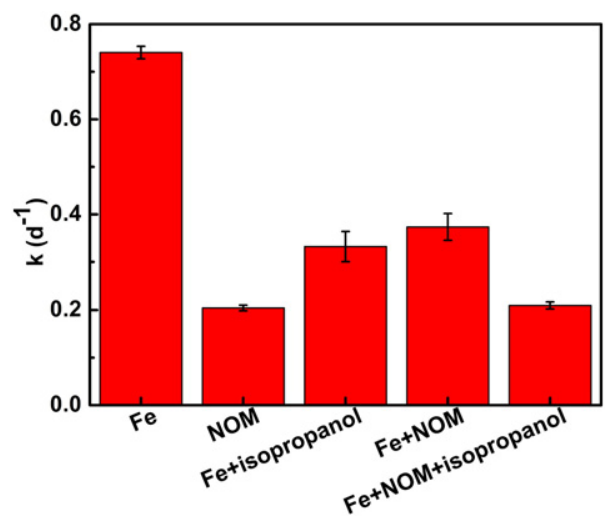

Fig. 1. Effect of $\mathrm{Fe}^{3+}$ and $\mathrm{NOM}$ on $\mathrm{MeHg}$ photodegradation rate under simulated sunlight. Conditions: $10 \mathrm{mmol} \mathrm{L}^{-1}$ phosphate buffer (pH 6.0), $2 \mu \mathrm{mol} \mathrm{L}^{-1} \mathrm{Fe}^{3+}$ or $2.0 \mathrm{mg} \mathrm{C} \mathrm{L}^{-1}$ NOM. The concentration of isopropanol was $100 \mathrm{mmol} \mathrm{L}^{-1}$. 
degradation under the solar spectrum (Tai et al., 2014). However, as a soft Lewis base, thiol in NOM can form a strong bond with $\mathrm{MeHg}$, which can weaken the $\mathrm{C}-\mathrm{Hg}$ bond and subsequently facilitate the degradation of MeHg (Melnick and Parkin, 2007; Ni et al., 2006; Tossell, 1998).

Fig. 1 also showed that the addition of hydroxyl radical scavenger, isopropanol, significantly decreased the photodegradation of $\mathrm{MeHg}$ induced by $\mathrm{Fe}^{3+}$, supporting the mechanism of hydroxyl radical-involved photo-Fenton reaction (Hammerschmidt and Fitzgerald, 2010). In addition, the MeHg photodegradation induced by $\mathrm{Fe}^{3+}$ significantly decreased in the presence of co-existing NOM, which could be ascribed to the depletion of hydroxyl radical by NOM (Vione et al., 2006; Westerhoff et al., 1999). This hypothesis was further validated by further adding isopropanol into the $\mathrm{Fe}^{3+}$-NOM solution. The depletion of hydroxyl radical by isopropanol decreased the photodegradation of $\mathrm{MeHg}$, and the resulting photodegradation rate $\left(0.210 \pm 0.007 \mathrm{~d}^{-1}\right)$ is comparable with that in the presence of NOM only $(0.205 \pm$ $0.006 \mathrm{~d}^{-1}$ ). The inhibition of $\mathrm{Fe}^{3+}$-induced photodegradation by NOM indicated that the underlying mechanism of NOM-induced $\mathrm{MeHg}$ photodegradation might be much different with that of $\mathrm{Fe}^{3+}$. These results also suggested that although $\mathrm{Fe}^{3+}$-produced hydroxyl radical can induce the degradation of $\mathrm{MeHg}$, the catalytic role of $\mathrm{Fe}^{3+}$ in natural water could be inhibited by the ubiquitous NOM. As the concentrations of $\mathrm{Fe}^{3+}$ and NOM in natural waters varies in different ecosystems (Hudson et al., 2007; Lofts et al., 2008), the relative importance of $\mathrm{Fe}^{3+}$ and NOM in the photodegradation of MeHg may be different among various natural ecosystems.

\subsection{Effects of pristine- and $\mathrm{M}_{f} \mathrm{NOM}$ on $\mathrm{MeHg}$ photodegradation}

We further studied the effect of concentration of pristine- and $\mathrm{M}_{\mathrm{f}}{ }^{-}$ NOM on the photodegradation of MeHg. As shown in Fig. 2a, the degradation rate of MeHg increased from 0.21 to $0.26 \mathrm{~d}^{-1}$ when NOM concentration increased from 1 to $2 \mathrm{mg} \mathrm{C} \mathrm{L}^{-1}$. However, further increase of NOM concentration significantly decreased the photodegradation of MeHg. This NOM-concentration dependent MeHg photodegradation should stem from a combined effect of NOM-concentration dependent formation of NOM-MeHg complex and light attenuation. It was reported that the formation MeHg-NOM complex is critical for $\mathrm{MeHg}$ photodegradation (Qian et al., 2014; Tai et al., 2014; Zhang and Hsu-Kim, 2010). It is reasonable that with the increase of NOM concentration, the fraction of MeHg as NOM-MeHg complex increased accordingly, which could increase the photodegradation of MeHg. Similar enhanced $\mathrm{MeHg}$ photodegradation with the increase of NOM concentration was also observed in other studies by using NOM model other than SRNOM (Qian et al., 2014; Zhang and Hsu-Kim, 2010). However, the increase of NOM concentration also enhances the light attenuation, which potentially inhibits the degradation of MeHg (Li et al., 2010).
Different degradation rates were observed for MeHg in various $\mathrm{M}_{\mathrm{f}^{-}}$ NOM solutions, as shown in Fig. 2a, which should be attributed to the difference of $\mathrm{M}_{\mathrm{f}}-\mathrm{NOM}$ in structure and optical characteristics. Interestingly, differential $\mathrm{M}_{\mathrm{f}}$-NOM concentration dependent $\mathrm{MeHg}$ photodegradation was also observed. As shown in Fig. 2a, the light attenuation-induced inhibition of $\mathrm{MeHg}$ photodegradation was more significant for high molecular weight $\mathrm{M}_{\mathrm{f}}-\mathrm{NOM}$ in comparison with their low molecular weight counterpart, due to the higher absorbance in UV-vis region by high molecular weight $\mathrm{M}_{\mathrm{f}}-\mathrm{NOM}$. For example, at $2 \mathrm{mg} \mathrm{C} \mathrm{L}{ }^{-1}$ concentration level of NOM, the degradation rate of MeHg in $>10 \mathrm{kDa} \mathrm{M}_{\mathrm{f}}-\mathrm{NOM}$ solution was significantly higher $(p<0.05)$ than that in $<3 \mathrm{kDa} \mathrm{M}_{\mathrm{f}}-\mathrm{NOM}$ solution, while at $40 \mathrm{mg} \mathrm{C} \mathrm{L}^{-1}$ concentration level of NOM, the degradation rate of $\mathrm{MeHg}$ in $>10 \mathrm{kDa} \mathrm{M}_{\mathrm{f}}-\mathrm{NOM}$ solution was quite similar to that in $<3 \mathrm{kDa} \mathrm{M}_{\mathrm{f}}-\mathrm{NOM}$ solution. The effect of light attenuation on $\mathrm{MeHg}$ photodegradation was further evaluated by using a monochromatic radiation $\left(366 \mathrm{~nm}\right.$ ) in pristine- and $\mathrm{M}_{\mathrm{f}}-\mathrm{NOM}$. As shown in Fig. $2 \mathrm{~b}$, the corrected degradation rates of $\mathrm{MeHg}$ ( $\left.k_{\lambda, \text { corrected }}\right)$ were comparable with that uncorrected in $2 \mathrm{mg} \mathrm{C} \mathrm{L}^{-1}$ NOM solution, suggesting the impact of light attenuation on $\mathrm{MeHg}$ photodegradation is not significant at low NOM concentration. However, as shown in Fig. 2c, in NOM solution at $40 \mathrm{mg} \mathrm{C} \mathrm{L}^{-1}$, the corrected degradation rates of $\mathrm{MeHg}$ in the presence of $\mathrm{M}_{\mathrm{f}}-\mathrm{NOM}$ increased significantly and were quite similar with that in low concentration NOM solution. This result demonstrated that the lower apparent degradation rates $\left(k_{\lambda}\right)$ in higher molecular weight $\mathrm{M}_{\mathrm{f}}-\mathrm{NOM}$ solutions at high NOM concentration were mainly ascribed to their stronger light attenuation effect than that of the lower molecular weight counterparts.

As light attenuation in water was primarily determined by NOM concentration (Donahue et al., 2003; Huovinen et al., 2003), the concentration of NOM should be one of the key factors controlling the photodegradation of $\mathrm{MeHg}$ in natural waters (Li et al., 2010). Our study further reveals that, in addition to NOM concentration, the NOM composition or molecular weight distribution also plays a critical role in the photodegradation of $\mathrm{MeHg}$. As environmental waters from different origins could have different molecular weight distributions, the photodegradation of MeHg in these surface waters may be also site-specific, especially at high NOM concentration.

\subsection{Effects of light quality on $\mathrm{MeHg}$ photodegradation}

Effects of simulated light quality on $\mathrm{MeHg}$ photodegradation in pristine NOM and different $\mathrm{M}_{\mathrm{f}}-\mathrm{NOM}$ were quite similar, which were given in Fig. 3. Compared with that under full simulated sunlight, no significant MeHg degradation in NOM solutions $\left(\mathrm{K}_{\mathrm{d}}<0.035 \mathrm{~d}^{-1}\right)$ was observed for that exposed under UV-block film, which indicated that the visible light in the simulated light played a minor role in the degradation of MeHg. This result also suggested that UV fraction in simulated sunlight played a major role (contribution $>83 \%$ ) in the degradation. Meanwhile, significant degradation of $\mathrm{MeHg}$ still could be observed in
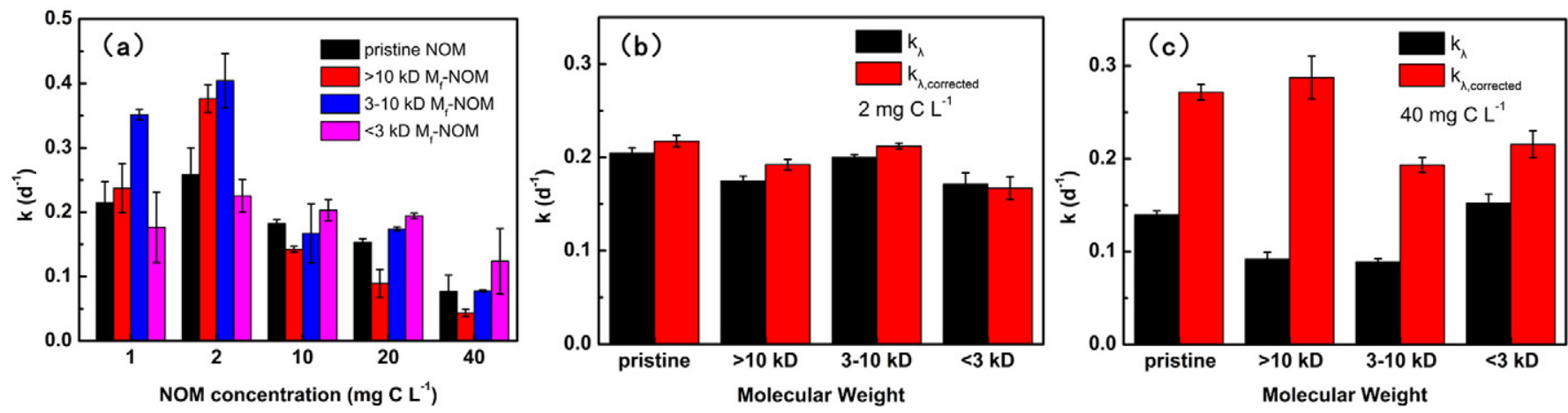

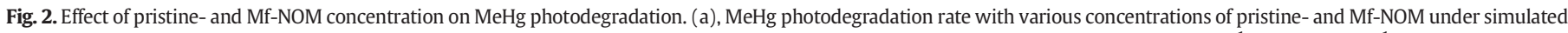

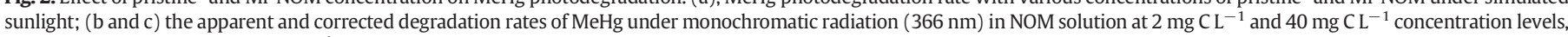
respectively. Conditions: $10 \mathrm{mmol} \mathrm{L}^{-1}$ phosphate buffer ( $\mathrm{pH} 7.4$ ). 


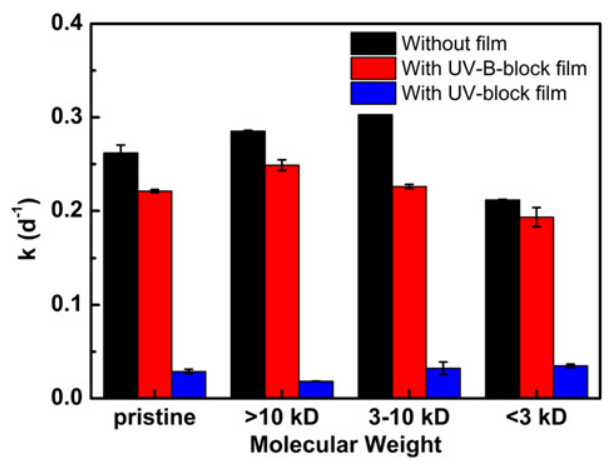

Fig. 3. Effects of light quality on MeHg photodegradation in the presence of pristine or Mf-

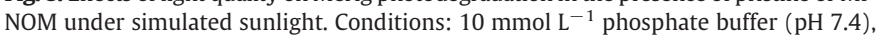
$2 \mathrm{mg} \mathrm{C} \mathrm{L}{ }^{-1}$ pristine or Mf-NOM.

solutions exposed under UV-B-block film, suggesting that UV-A fraction played a critical role (average contribution $73.3 \%$ ) in $\mathrm{MeHg}$ photodegradation in our experimental settings. The contribution of UV-A fraction in $\mathrm{MeHg}$ photodegradation in our simulated sunlight was comparable with previous study under natural sunlight $(\sim 85 \%)$ (Li et al., 2010), although different light sources were used.

\subsection{Influence of $\mathrm{pH}$ on $\mathrm{MeHg}$ photodegradation}

The influence of $\mathrm{pH}$ (5.0-9.0) on MeHg photodegradation in de-ionized water was firstly investigated (Fig. S5). The results suggested that at all investigated $\mathrm{pH}$ the photodegradation of $\mathrm{MeHg}$ was negligible in de-ionized water. The effect of $\mathrm{pH}$ on $\mathrm{MeHg}$ photodegradation was further investigated in the presence of pristine- and $\mathrm{M}_{\mathrm{f}}-\mathrm{NOM}$. As shown in Fig. S6, the $\mathrm{pH}$ had no significant effect on the degradation rate of $\mathrm{MeHg}$ at $\mathrm{pH}$ from 5.0-7.0. However, a decrease $(p<0.05$ for pristine NOM and $<3 \mathrm{kDa} \mathrm{M}_{\mathrm{f}}-\mathrm{NOM}, p<0.1$ for $\left.>10 \mathrm{kDa} \mathrm{M}_{\mathrm{f}}-\mathrm{NOM}\right)$ at $\mathrm{pH} 8.0$ and then an increase ( $p<0.05$ for pristine NOM and all $\mathrm{M}_{\mathrm{f}}-\mathrm{NOM}$ ) of degradation rate at $\mathrm{pH} 9.0$ were observed. The influence of $\mathrm{pH}$ on the photodegradation of $\mathrm{MeHg}$ seemed complicated. On one hand, the influence of $\mathrm{pH}$ on $\mathrm{MeHg}$ photodegradation was mainly due to the coordination balance of NOM-MeHg complexes. Higher $\mathrm{pH}$ could promote the dissociation of thiol in NOM (Karlsson and Skyllberg, 2003) and NOM-MeHg complexes formation (Amirbahman et al., 2002), which could accelerate the subsequent $\mathrm{MeHg}$ photodegradation. On the other hand, lower $\mathrm{pH}$ could increase the photobleaching of NOM (Anesio and Granéli, 2003), which could then enhance the degradation of $\mathrm{MeHg}$ due to the increased light penetration (Tai et al., 2014) and concurrent photolytic degradation of NOM with MeHg (Fleck et al., 2014).

\section{5. $\mathrm{MeHg}$ photodegradation in the presence of $\mathrm{Cl}^{-}$}

Chloride ions widely exist in surface water at various concentrations (up to $0.5 \mathrm{~mol} \mathrm{~L}^{-1}$ ). In our study, in the presence of $2 \mathrm{mg} \mathrm{C} \mathrm{L}^{-1}$ pristineor $\mathrm{M}_{\mathrm{f}}-\mathrm{NOM}$, the effect of $\mathrm{Cl}^{-}\left(0-800 \mathrm{mmol} \mathrm{L}^{-1}\right)$ on photodegradation of $\mathrm{MeHg}$ was investigated. As shown in Fig. 4, the degradation rates of $\mathrm{MeHg}$ increased with $\mathrm{NaCl}$ concentration up to $10 \mathrm{mmol} \mathrm{L}^{-1}$. However, further increasing the concentration of $\mathrm{NaCl}$ from 100 to $800 \mathrm{mmol} \mathrm{L}^{-1}$ significantly decreased the degradation rates of $\mathrm{MeHg}$. The enhancement of $\mathrm{MeHg}$ photodegradation by $\mathrm{Cl}^{-}$is probably a consequence of the photo-generated chlorine radicals-induced degradation of $\mathrm{MeHg}$ (Chen et al., 2003). In addition, the increasing ionic strength could also increase the absorbance of NOM (Gao et al., 2015), which could subsequently enhance the NOM-mediated $\mathrm{MeHg}$ photodegradation. However, with the further increase of $\mathrm{Cl}^{-}$concentration, the fraction of $\mathrm{MeHg}$ complexed with NOM would decrease accompanying with the increasing fraction of $\mathrm{MeHg}$ as $\mathrm{MeHgCl}$ (Zhang and Hsu-Kim, 2010). As the direct photodegradation of $\mathrm{MeHgCl}$ (Tossell, 1998) was theoretically impossible under solar radiation or simulated light under our

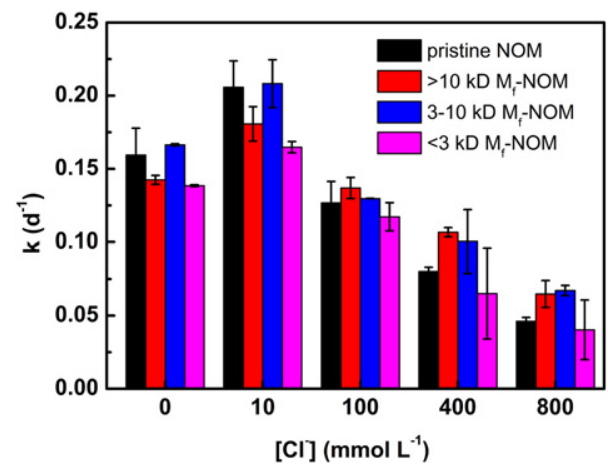

Fig. 4. Effect of $\mathrm{Cl}^{-}$on MeHg photodegradation in the presence of pristine or Mf-NOM under simulated sunlight. Conditions: $10 \mathrm{mmol} \mathrm{L}^{-1}$ phosphate buffer (pH 7.4), $2 \mathrm{mg}$ $\mathrm{C} \mathrm{L}^{-1}$ pristine or Mf-NOM.

experimental setting, high concentration of $\mathrm{Cl}^{-}$is expected to inhibit the photodegradation of MeHg. Since the composition and structural characteristics of NOM varies in different ecosystems, the competitive binding behavior of $\mathrm{Cl}^{-}$and NOM from different sources with $\mathrm{MeHg}$ might be different, possibly resulting in different degradation behaviors of $\mathrm{MeHg}$ in $\mathrm{Cl}^{-}$and NOM-co-existing surface waters. For example, the minor influence of $\mathrm{Cl}^{-}$on the photodegradation of MeHg in Florida Everglades water (Tai et al., 2014) could be ascribed to its higher abundance of reduced thiol in NOM, which can strengthen the binding of NOM with MeHg.

\section{6. $\mathrm{MeHg}$ photodegradation in the presence of $\mathrm{NO}_{3}^{-}$}

Previous studies have demonstrated that sunlight irradiation of $\mathrm{NO}_{3}^{-}$ can generate hydroxyl radicals (Shankar et al., 2007; Vaughan and Blough, 1998; Zepp et al., 1987), which can decompose MeHg (Chen et al., 2003; Gårdfeldt et al., 2001). The ubiquitous $\mathrm{NO}_{3}^{-}$could also play a potential role in the photodegradation of $\mathrm{MeHg}$ through a hydroxyl radicals-involved decomposition of $\mathrm{MeHgCl}$ (Chen et al., 2003). However, the role of $\mathrm{NO}_{3}^{-}$in $\mathrm{MeHg}$ photodegradation in the presence of NOM is still not known. As shown in Fig. 5 , in $2 \mathrm{mg} \mathrm{C} \mathrm{L}^{-1}$ pristineor $\mathrm{M}_{\mathrm{f}}-\mathrm{NOM}$ solutions (except for the 3-10 kDa $\mathrm{M}_{\mathrm{f}}-\mathrm{NOM}$ ), the photodegradation rate of $\mathrm{MeHg}$ increased with the $\mathrm{NO}_{3}^{-}$concentration up to $0.1 \mathrm{mmol} \mathrm{L}^{-1}$, and then decreased with the further increase of $\mathrm{NO}_{3}^{-}$concentration. This $\mathrm{NO}_{3}^{-}$-enhanced $\mathrm{MeHg}$ photodegradation could be ascribed to $\mathrm{NO}_{3}^{-}$-produced hydroxyl radicals (Mack and Bolton, 1999). However, the further increase of $\mathrm{NO}_{3}^{-}$concentration also increases the accumulation of its photolysis product, $\mathrm{NO}_{2}^{-}$, which has strong light absorption at UV-A region (Vione et al., 2014). The accumulation of high concentration of $\mathrm{NO}_{2}^{-}$could increase the light

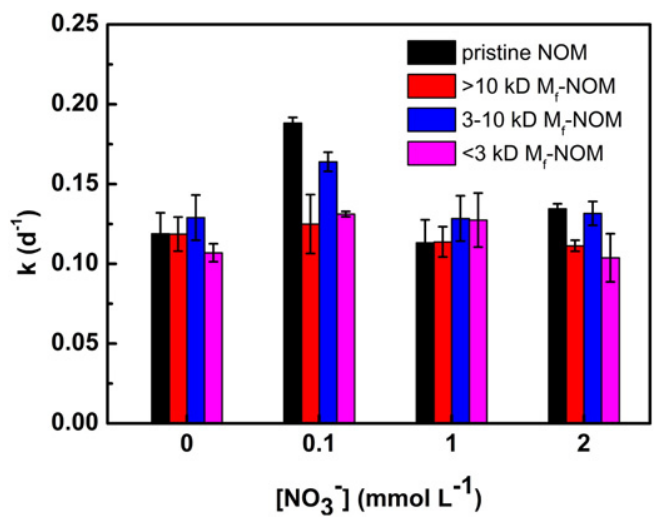

Fig. 5. Effect of $\mathrm{NO} 3$ - on $\mathrm{MeHg}$ photodegradation in the presence of pristine or Mf-NOM

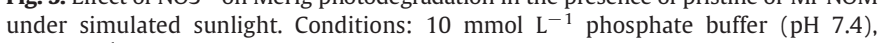
$2 \mathrm{mg} \mathrm{C} \mathrm{L}{ }^{-1}$ pristine or Mf-NOM. 
attenuation in the solution, which further inhibits the photodegradation of MeHg (Li et al., 2010). The almost constant photodegradation rate of $\mathrm{MeHg}$ at various concentration of $\mathrm{NO}_{3}^{-}$in the presence of $>10 \mathrm{kDa} \mathrm{M}_{\mathrm{f}^{-}}$ NOM could also ascribed to the strong light attenuation of high molecular weight NOM.

\section{Conclusions}

In this study, we investigated the effects of environmental factors on MeHg photodegradation. These factors included pristine- and $\mathrm{M}_{\mathrm{f}}-\mathrm{NOM}$ concentrations, light quality, $\mathrm{pH}$, and co-existing $\mathrm{Cl}^{-}, \mathrm{NO}_{3}^{-}$, and $\mathrm{Fe}^{3+}$ under simulated sunlight. Our results demonstrated $\mathrm{Fe}^{3+}$-mediated photo-Fenton reaction can induce $\mathrm{MeHg}$ photodegradation (Hammerschmidt and Fitzgerald, 2010), however, the co-existing NOM can partially inhibit the $\mathrm{Fe}^{3+}$-induced $\mathrm{MeHg}$ degradation. The NOM-induced MeHg photodegradation was affected by its structure characteristics, complexation with MeHg (Qian et al., 2014; Tai et al., 2014; Zhang and Hsu-Kim, 2010) and light attenuation (Fernandez-Gomez et al., 2013; Li et al., 2010). This light attenuation-induced degradation inhibition was more significant for high molecular weight $\mathrm{M}_{\mathrm{f}}-\mathrm{NOM}$. Photodegradation-mediated by NOM is also directly or indirectly affected by $\mathrm{pH}$ and co-existing $\mathrm{Cl}^{-}$and $\mathrm{NO}_{3}^{-}$. The $\mathrm{Cl}^{-}$and $\mathrm{NO}_{3}^{-}$-enhanced $\mathrm{MeHg}$ photodegradation in the presence of NOM suggested multiple reaction pathways may be involved in $\mathrm{MeHg}$ photodegradation (Black et al., 2012), while photodegradation inhibition at high concentration of $\mathrm{Cl}^{-}$demonstrated the importance of NOM-MeHg complexation in MeHg photodegradation (Qian et al., 2014; Tai et al., 2014; Zhang and Hsu-Kim, 2010). Considering the different water chemistry (concentration and composition of NOM, $\mathrm{pH}$, co-existing $\mathrm{Fe}^{3+}, \mathrm{Cl}^{-}$, and $\mathrm{NO}_{3}^{-}$) in surface waters from different sites, the photodegradation of $\mathrm{MeHg}$ in these surface waters should also be highly site-specific and multiple reaction pathways may be involved.

\section{Acknowledgements}

This study was financially supported by the National Key Basic Research Program of China (2013CB430002), and National Natural Science Foundation of China (21120102040, 21321004, and 21522705).

\section{Appendix A. Supplementary data}

The supporting information includes a summary of the characterization of pristine and $\mathrm{M}_{\mathrm{f}}-\mathrm{NOM}$, the molecular weight distribution of $\mathrm{M}_{\mathrm{f}^{-}}$ NOM fraction in SRNOM, UV-vis and fluorescence excitation-emission spectra of pristine- and $\mathrm{M}_{\mathrm{f}}-\mathrm{NOM}$, MeHg degradation in deionized water under simulated sunlight or in NOM solution under dark, the effect of $\mathrm{pH}$ on $\mathrm{MeHg}$ photodegradation in deionized water or pristine/ $\mathrm{M}_{\mathrm{f}}-\mathrm{NOM}$ solution. Supplementary data associated with this article can be found in the online version, at http://dx.doi.org/10.1016/j.scitotenv. 2016.10.222.

\section{References}

Amirbahman, A., Reid, A.L., Haines, T.A., Kahl, J.S., Arnold, C., 2002. Association of methylmercury with dissolved humic acids. Environ. Sci. Technol. 36, 690-695.

Anesio, A.M., Granéli, W., 2003. Increased photoreactivity of DOC by acidification: implications for the carbon cycle in humic lakes. Limnol. Oceanogr. 48, 735-744.

Black, F.J., Poulin, B.A., Flegal, A.R., 2012. Factors controlling the abiotic photo-degradation of monomethylmercury in surface waters. Geochim. Cosmochim. Acta 84, 492-507.

Chen, J., Pehkonen, S.O., Lin, C.J., 2003. Degradation of monomethylmercury chloride by hydroxyl radicals in simulated natural waters. Water Res. 37, 2496-2504.

Donahue, W.F., Turner, M.A., Findlay, D.L., Leavitt, P.R., 2003. The role of solar radiation in structuring the shallow benthic communities of boreal forest lakes. Limnol. Oceanogr. $48,31-47$

Fernandez-Gomez, C., Drott, A., Bjorn, E., Diez, S., Bayona, J.M., Tesfalidet, S., Lindfors, A., Skyllberg, U., 2013. Towards universal wavelength-specific photodegradation rate constants for methyl mercury in humic waters, exemplified by a boreal lake-wetland gradient. Environ. Sci. Technol. 47, 6279-6287.
Fleck, J.A., Gill, G., Bergamaschi, B.A., Kraus, T.E.C., Downing, B.D., Alpers, C.N., 2014. Concurrent photolytic degradation of aqueous methylmercury and dissolved organic matter. Sci. Total Environ. 484, 263-275.

Fleming, E.J., Mack, E.E., Green, P.G., Nelson, D.C., 2006. Mercury methylation from unexpected sources: molybdate-inhibited freshwater sediments and an iron-reducing bacterium. Appl. Environ. Microbiol. 72, 457-464.

Gao, Y., Yan, M.Q., Korshin, G.V., 2015. Effects of ionic strength on the chromophores of dissolved organic matter. Environ. Sci. Technol. 49, 5905-5912.

Gårdfeldt, K., Sommar, J., Strömberg, D., Feng, X.B., 2001. Oxidation of atomic mercury by hydroxyl radicals and photoinduced decomposition of methylmercury in the aqueous phase. Atmos. Environ. 35, 3039-3047.

Gilmour, C.C., Henry, E.A., Mitchell, R., 1992. Sulfate stimulation of mercury methylation in freshwater sediments. Environ. Sci. Technol. 26, 2281-2287.

Hammerschmidt, C.R., Fitzgerald, W.F., 2006. Photodecomposition of methylmercury in an arctic Alaskan lake. Environ. Sci. Technol. 40, 1212-1216.

Hammerschmidt, C.R., Fitzgerald, W.F., 2010. Iron-mediated photochemical decomposition of methylmercury in an arctic Alaskan lake. Environ. Sci. Technol. 44, 6138-6143.

Hines, N.A., Brezonik, P.L., 2007. Mercury inputs and outputs at a small lake in northern Minnesota. Biogeochemistry 84, 265-284.

Hudson, N., Baker, A., Reynolds, D., 2007. Fluorescence analysis of dissolved organic matter in natural, waste and polluted waters - a review. River Res. Appl. 23, 631-649.

Huovinen, P.S., Penttila, H., Soimasuo, M.R., 2003. Spectral attenuation of solar ultraviolet radiation in humic lakes in Central Finland. Chemosphere 51, 205-214.

Julvez, J., Debes, F., Weihe, P., Choi, A., Grandjean, P., 2010. Sensitivity of continuous performance test (CPT) at age 14 years to developmental methylmercury exposure. Neurotoxicol. Teratol. 32, 627-632.

Karlsson, T., Skyllberg, U., 2003. Bonding of ppb levels of methyl mercury to reduced sulfur groups in soil organic matter. Environ. Sci. Technol. 37, 4912-4918.

Khwaja, A.R., Bloom, P.R., Brezonik, P.L., 2010. Binding strength of methylmercury to aquatic NOM. Environ. Sci. Technol. 44, 6151-6156.

Kim, M.K., Zoh, K.D., 2013. Effects of natural water constituents on the photo-decomposition of methylmercury and the role of hydroxyl radical. Sci. Total Environ. 449, 95-101.

Lehnherr, I., St. Louis, V.L., 2009. Importance of ultraviolet radiation in the photodemethylation of methylmercury in freshwater ecosystems. Environ. Sci. Technol. 43, 5692-5698.

Li, Y.B., Mao, Y.X., Liu, G.L., Tachiev, G., Roelant, D., Feng, X.B., Cai, Y., 2010. Degradation of methylmercury and its effects on mercury distribution and cycling in the Florida Everglades. Environ. Sci. Technol. 44, 6661-6666.

Lofts, S., Tipping, E., Hamilton-Taylor, J., 2008. The chemical speciation of Fe(III) in freshwaters. Aquat. Geochem. 14, 337-358.

Ma, X., Yin, Y.G., Shi, J.B., Liu, J.F., Jiang, G.B., 2014. Species-specific isotope dilution-GCICP-MS for accurate and precise measurement of methylmercury in water, sediments and biological tissues. Anal. Methods 6, 164-169.

Mack, J., Bolton, J.R., 1999. Photochemistry of nitrite and nitrate in aqueous solution: a review. J. Photochem. Photobiol. A Chem. 128, 1-13.

Marvin-Dipasquale, M.C., Oremland, R.S., 1998. Bacterial methylmercury degradation in Florida Everglades peat sediment. Environ. Sci. Technol. 32, 2556-2563.

Melnick, J.G., Parkin, G., 2007. Cleaving mercury-alkyl bonds: A functional model for mercury detoxification by MerB. Science 317, 225-227.

Mergler, D., Anderson, H.A., Chan, L.H.M., Mahaffey, K.R., Murray, M., Sakamoto, M., Stern, A.H., 2007. Methylmercury exposure and health effects in humans: a worldwide concern. Ambio 36, 3-11.

Morel, F.M.M., Kraepiel, A.M.L., Amyot, M., 1998. The chemical cycle and bioaccumulation of mercury. Annu. Rev. Ecol. Syst. 29, 543-566.

Mostofa, K.M.G., Liu, C.Q., Mottaleb, M.A., Wan, G.J., Ogawa, H., Vione, D., Yoshioka, T., Wu, F.C., 2013. Dissolved organic matter in natural waters. In: Mostofa, M.G.K., Yoshioka, T., Mottaleb, A., Vione, D. (Eds.), Photobiogeochemistry of Organic Matter: Principles and Practices in Water Environments. Springer Berlin Heidelberg, Berlin, Heidelberg pp. 1-137.

Ni, B., Kramer, J.R., Bell, R.A., Werstiuk, N.H., 2006. Protonolysis of the Hg-C bond of chloromethylmercury and dimethylmercury. A DFT and QTAIM study. J. Phys. Chem. A 110, 9451-9458

Oremland, R.S., Culbertson, C.W., Winfrey, M.R. 1991. Methylmercury decomposition in sediments and bacterial cultures - involvement of methanogens and sulfate reducers in oxidative demethylation. Appl. Environ. Microbiol. 57, 130-137.

Parks, J.M., Johs, A., Podar, M., Bridou, R., Hurt, R.A., Smith, S.D., Tomanicek, S.J., Qian, Y., Brown, S.D., Brandt, C.C., Palumbo, A.V., Smith, J.C., Wall, J.D., Elias, D.A., Liang, L.Y., 2013. The genetic basis for bacterial mercury methylation. Science 339, $1332-1335$.

Peuravuori, J., Pihlaja, K., 1997. Molecular size distribution and spectroscopic properties of aquatic humic substances. Anal. Chim. Acta 337, 133-149.

Qian, Y., Yin, X.P., Lin, H., Rao, B.L., Brooks, S.C., Liang, L.Y., Gu, B.H., 2014. Why dissolved organic matter enhances photodegradation of methylmercury. Environ. Sci. Technol. Lett. 1, 426-431.

Richard, C., Trubetskaya, O., Trubetskoj, O., Reznikova, O., Afanas'eva, G., Aguer, J.P., Guyot G., 2004. Key role of the low molecular size fraction of soil humic acids for fluorescence and photoinductive activity. Environ. Sci. Technol. 38, 2052-2057.

Rong, X., Waite, D., Huang, G.H., Tong, L., Kybett, B., 2001. Materials selection for a dry atmospheric mercury deposits sampler. Chemosphere 45, 1045-1051.

Schaefer, J.K., Yagi, J., Reinfelder, J.R., Cardona, T., Ellickson, K.M., Tel-Or, S., Barkay, T., 2004. Role of the bacterial organomercury lyase (MerB) in controlling methylmercury accumulation in mercury-contaminated natural waters. Environ. Sci. Technol. 38, 4304-4311.

Sellers, P., Kelly, C.A., Rudd, J.W.M., MacHutchon, A.R., 1996. Photodegradation of methylmercury in lakes. Nature 380, 694-697. 
Shankar, M.V., Nélieu, S., Kerhoas, L., Einhorn, J., 2007. Photo-induced degradation of diuron in aqueous solution by nitrites and nitrates: kinetics and pathways. Chemosphere 66, 767-774.

Shen, M.H., Yin, Y.G., Booth, A., Liu, J.F., 2015. Effects of molecular weight-dependent physicochemical heterogeneity of natural organic matter on the aggregation of fullerene nanoparticles in mono- and di-valent electrolyte solutions. Water Res. 71, 11-20.

Sun, R.G., Wang, D.Y., Zhang, Y.T., Mao, W., Zhang, T., Ma, M., Zhang, C., 2013. Photo-degradation of monomethylmercury in the presence of chloride ion. Chemosphere 91, 1471-1476.

Tai, C., Li, Y.B., Yin, Y.G., Scinto, L.J., Jiang, G.B., Cai, Y., 2014. Methylmercury photodegradation in surface water of the Florida Everglades: importance of dissolved organic matter-methylmercury complexation. Environ. Sci. Technol. 48, 7333-7340.

Tossell, J.A., 1998. Theoretical study of the photodecomposition of methyl Hg complexes. J. Phys. Chem. A 102, 3587-3591.

Vaughan, P.P., Blough, N.V., 1998. Photochemical formation of hydroxylradical by constituents of natural waters. Environ. Sci. Technol. 32, 2947-2953.

Vione, D., Falletti, G., Maurino, V., Minero, C., Pelizzetti, E., Malandrino, M., Ajassa, R. Olariu, R.I., Arsene, C., 2006. Sources and sinks of hydroxyl radicals upon irradiation of natural water samples. Environ. Sci. Technol. 40, 3775-3781.

Vione, D., Minella, M., Maurino, V., Minero, C., 2014. Indirect photochemistry in sunlit surface waters: photoinduced production of reactive transient species. Chem. Eur. J. 20 10590-10606.
Westerhoff, P., Aiken, G., Amy, G., Debroux, J., 1999. Relationships between the structure of natural organic matter and its reactivity towards molecular ozone and hydroxyl radicals. Water Res. 33, 2265-2276.

Whalin, L., Kim, E.H., Mason, R., 2007. Factors influencing the oxidation, reduction, methylation and demethylation of mercury species in coastal waters. Mar. Chem. 107, 278-294.

Yin, Y.G., Shen, M.H., Zhou, X.X., Yu, S.J., Chao, J.B., Liu, J.F., Jiang, G.B., 2014. Photoreduction and stabilization capability of molecular weight fractionated natural organic matter in transformation of silver ion to metallic nanoparticle. Environ. Sci. Technol. 48, 9366-9373.

Zepp, R.G., Faust, B.C., Holgné, J., 1992. Hydroxyl radical formation in aqueous reactions ( $\mathrm{pH} 3-8)$ of iron (II) with hydrogen peroxide: the photo-Fenton reaction. Environ. Sci. Technol. 26, 313-319.

Zepp, R.G., Hoigne, J., Bader, H., 1987. Nitrate-induced photooxidation of trace organic chemicals in water. Environ. Sci. Technol. 21, 443-450.

Zhang, T., Hsu-Kim, H., 2010. Photolytic degradation of methylmercury enhanced by binding to natural organic ligands. Nat. Geosci. 3, 473-476. 